\title{
invotec
}

The International Journal of Technical and Vocational Education

UPI JOURNAL

Available online at http://invotec.fptk.upi.edu

\section{TVET Capacity Development in Afghanistan: Introducing Self-Reliant Internship in In-Service Technical Teacher Training at the Technical Teacher Training Institute (TTTI)}

\author{
D. Klee, Andar
}

Technical Teacher Training Institute, Kabul, Afghanistan

ARTICLE INFO

\section{Article history:}

Received 3 September 2014

Received in revised form 8

July 2015

Accepted 13 November 2015

Available online 11 December

2015

Keywords:

In-service TVET teacher training

Self-reliant internship

Holistic work process

Didactics

Evidence based

Closed loop

Corresponding author:

daniel.klee@web.de

\author{
A B STR A C T
}

This paper describes the approach applied to the introduction of self-reliant internship into the in-service TVET (Technical Vocational Education and Training) teacher training at the Technical Teacher Training Institute (TTTI) in Afghanistan. As data show in 2014, Afghan TVET teachers neither meet the legal requirements set by the government (Bachelor degree) nor have contacts to or work experiences in private or public sector companies. They have no knowledge of the working requirements they are preparing their students for. Consequently, in-service teacher training at the TTTI has to provide it's learners with knowledge and skills in accordance with the market requirements. Thus, at the TTTI Capacity Building is focusing among others on the multifaceted interdependent relationship between teacher-student-company in order to empower teachers to be able to contribute to the employability of their students. In this respect TTTI's in-service teacher training foresees the teacher's participation in a private or public sector self-reliant internship to benefit from the expertise of companies' work force and employers and actualize their understanding for the world of work. Afghan TVET teachers completing successful the TTTI in-service training are able to train many cohorts of students for the labor market or self-employment with the gained competences. Two subsequent cohorts of TTTI trainees - government employed TVET teachers undergoing in-service teacher training - have been participating for their first time in self-reliant internship in 2013 and 2014. According to the findings, recommendations are given for using the approach of introducing internship in in-service training for TVET teacher capacity building. 


\section{Introduction}

In September 2013, in Kabul, Afghanistan, the Technical Teacher Training Institute opened its doors under the Ministry of Educations' Deputy Ministry TVET (DM-TVET) falling under the Afghanistan Second Skills Development Project (ASDP II) funded by the World Bank. TTTI's mandate is to upgrade Technical Vocational Education and Training (TVET) teachers skills through in-service TVET teacher training for teachers currently employed in TVET and to come up with a set of Afghan Master Trainers who will be able to train other TVET teachers. All courses (e.g. subject area, technical math, vocational pedagogy and ICT) are offered in a modular way and held in English language. Upon enrolment the teachers become trainee of the TTTI. TTTI will cater for all TVET teachers of Afghanistan once the hostels and workshops are in place. Upon enrolment at TTTI the teacher status becomes that of a trainee. At present all trainees are working in the Kabul area. As data show, in 2014, 48\% of Afghan TVET teachers (Word Bank, 2013) do neither meet the legal requirements set by the government (Bachelor degree) nor have contacts to or work experiences in private or public sector companies. They have no knowledge of the working requirements they are preparing their students for; see also table 1 below. At the same time employers in Afghanistan have a high demand for skilled and professional employees as a study by USAID shows,(USAID, 2012). Consequently, in-service teacher training at the TTTI has to provide it's learners with knowledge and skills in accordance with the market requirements. Thus, at the TTTI Capacity Building is focusing also on the multifaceted interdependent relationship between teacher- student- company in order to empower teachers to be able to contribute to the employability of their students. The data below describe the academic and practical background of the TVET teachers who have applied to study at TTTI since October 2013.

Table 1

Formal qualification and work experience of TVET teachers registered at TTTI

\begin{tabular}{llll}
\hline Grade & $\begin{array}{l}\text { No. of } \\
\text { applicants }\end{array}$ & $\begin{array}{l}\text { Distribution } \\
{[\%]}\end{array}$ & $\begin{array}{l}\text { No. of applicants stating to have } \\
\text { working experience in the private } \\
\text { sector. }\end{array}$ \\
\hline 14th grade* & 41 & 23 & 5 \\
Bachelor; BA & 67 & 37 & 9 \\
Bachelor; BS & 53 & 30 & 5 \\
Master; MA & 8 & 4 & 2 \\
Master; MS & 10 & 6 & 1 \\
\hline Total & 179 & 100 & 22 \\
\hline${ }^{*}$ The Afghan Law of Higher education states that a TVET teacher has to have as a minimum qualification a Bachelor degree.
\end{tabular}

$23 \%$ of the trainees registered at TTTI do not meet the legal minimum qualification criterion (Bachelor), which is corresponding to the overall figure of $48 \%$, (USAID, 2012). From the 45 female trainees, $25 \%$ of registered trainees, one holds a 14th grade degree, 27 Bachelor of Art (BA), 9 Bachelor of Science (BS), 3 Master of Art (MA) and 5 Master of Science (MS) degrees. The duration of having had work experience in the world of work's private sector ranges from 2 month to 15 years. The duration of having work experience from the public sector ranges from 2 months to 6 years and six month. 15 trainees (8\%) state to have both private and public sector working experience. Data does not confirm whether this is relevant work experience for the subject taught at present. Teachers enrolled at TTTI stating to have had working experience are 22 trainees or $12 \%$. Data show that the majority (88\%) of TTTI trainees have no knowledge of the world of work they are preparing their students for.

The impact of this crucial lack of knowledge can be described as following. In Afghanistan, a teacher receives during his/her work life time every year a new cohort of about 30 students (class numbers are according to TTTI trainees sometimes much higher, above 40 and more) multiplied by the teachers working life of about 40 years this would impact the training of about 1200 students per teacher. This impact during the working life is another reason why a teacher should be constantly acquainted with the world of work they 
are preparing their students for. The information above and the traditional institutional placement approach led to a discussion at TTTI to schedule a self-reliant internship allowing the TTTI trainees to get into contact with the world of work according to their needs. The Department of Capacity Building was in charge to develop and introduce self- reliant internships for the TTTI trainees.

\section{Methodological Approach}

The purpose of the TTTI in-service teacher training internship is to make the trainees aware of and acquaint with the world of work (companies, institutes, organizations) relevant to the subjects they are teaching. Further, trainees are in charge to find in a self-reliant manner a corresponding internship place, instead of being placed by TTTI. (Presently, it is the obligation of state run institutes to do the placement "guaranteeing" everybody an internship place, no matter if the institution or the place is fit to serve the needs of the student).

The rationale for the self-reliant approach is to be seen in relation with a behavioral connotation; to become actively relaying on own resources and abilities, in managing the accomplishment of one's own professional requirements. Part of the TTTI methodological approach is to empower the TTTI trainees by going through the entire cycle of finding a relevant internship place on their own, so the TTTI trainees then can serve their further advancements, e.g. deepening the cooperation or receiving further trainings by the world of work. The TTTI trainee is expected to conduct a company research (newspapers, online, friends), identify suitable places, manage to get interviews (phone calls, visits), writing an application, preparing a CV, introducing him or herself, laying down the intention for an internship and to stand the negotiations regarding the content of the internship and finally to participate actively in the internship. It is also expected by the selfreliant methodological approach, that the TTTI trainees become more able to serve their students better based on their experiences and contacts with the world of work.

Due to the present safety situation TTTI trainees are requested to consult with relevant authorities, the company and TTTI in order to be able to judge about the appropriateness for their safety. In case a company has to be changed, TTTI exerts appropriate flexibility. Due to the security situation in Afghanistan great attention is paid to the trainees well being. In order to search for best practices TTTI encourages its trainees to seek established private companies meeting TTTl's criteria (e.g. established more than five years, no criminal record, corresponding to the field of teaching). TTTI internship is scheduled in Vocational Pedagogy in order to integrate methodic and didactics around the corresponding triangle of teacher (trainees), students and company and how the TTTI trainees can enable their students best for the world of work. Since at the present stage TTTI trainees also serve as teachers at their workplace the internship is limited to seven consecutive days. The TTTI trainees' participation is obligatory as it is the filled in and signed Internship Diary. Participation and Internship Diary are both a policy prerequisite to be allowed to participate in the final exam. A verified didactical in-service training theory and approach for in-service training in conflict countries does not exist, therefore established approaches were considered as much as possible. The TTTI in-service TVET teacher training methodological approach foresees seven interdependent phases for the trainees:

\subsection{Awareness phase}

The awareness phase starts before students even enroll at the TTTI, e.g. during institutional and course promotion and is continued upon registry (receiving a course leaflet) and at the TTTI introduction day where potential or new TTTI trainees are again made aware that during their enrolment at TTTI they are to undergo a self-reliant internship and that the trainees are in charge to find a suitable internship place in the world of work corresponding to the subject they are teaching.

\subsection{Preparation Phase}

The preparation pays special attention in order to enable the individual trainees in finding an internship place in a self-reliant manner. With the start of the lessons in Vocational Pedagogy, trainees are increasingly made aware of the importance of keeping their TVET knowledge and skills updated for their students. This 
is why the internship has to be corresponding to the needs of and subjects taught by trainees. Worries of the trainees are collected and dealt with in a participatory manner- or specific methodological support is given, such as role play; TTTI trainees are taking on the role of the hiring HR manager or the company owner. A common understanding of the necessity to know about the world of work fosters the trainees' commitment to participate successfully in such a type of internship. Also the fact, that - unlike in a placement approach TTTI trainees recognize that their needs are considered, helps the trainees to embrace the self-reliant approach. Intense coaching on how to find an appropriate internship place goes along with judging the quality of the internship place or to consider experiences from previous students. The TTTI Internship Diary is handed at the beginning of the course to the students and each section is explained step by step. The TTTI Internship Diary considers a didactical concept, guiding the trainees in identifying how to connect their teaching closer to the world of work.

\subsection{Participation and mentoring Phase}

While at the internship work place the TTTI trainees' relation is with regard to safety and working relations entirely between the trainee and the employer (the legal status of a trainee might vary from place to place) and TTTI trainees are clearly instructed to follow the company rules and regulations and the world of work's code of conduct. TTTI's faculty is available for consultation during the usual lesson hours via email or phone in case trainees are encountering situations where advice is needed. At the workplace, the Internship Diary is now supporting the trainee, drawing the attention to work and business processes in a holistic manner, e.g. "What happened at each work station?", "Where do the different work and / or business processes start and end?", "How are they connected?", "Where does the customer come into play?" and to reflect on the observations made with regard to the improvement of their own teaching. The trainee is also tasked to identify an element he/she thinks is worthwhile for their students to know and to incorporate this into a demonstration lesson at the end of the semester, which serves also as the final exam. Mentoring and management visits happen upon request by either the trainee or the employer, or in case of doubt of participation. However, these visits are to be balanced well, since resources are limited.

\subsection{Evaluation Phase}

Evaluation of internship and experiences made takes place in an open forum, where trainees share their experiences with their peers, the TTTI management and faculty. The experience made is also documented in the trainees Internship Diary which can serve as evidence based data for the "Academic and closed loop phase" below, as well as information for teaching staff on e.g. status of English level (syntax, vocabulary, academic writing) or to be used by different departments to support the development of interdisciplinary teaching or projects. The evaluation of the TTTI internship approach foresees a feedback from various sides to identify areas of improvement and for lessons learnt.

Table 2

Potential areas of feedback by internship parties

Trainees feedback on:

Companies' support

Internship content and learning effect

TTTI preparation and educational modules

Areas of improvement for TVET
Company feedback on;

Trainee's performance

Further cooperation with trainee

Further cooperation with TTTI

Areas of improvement for TVET 


\subsection{Exam Phase}

The TTTI internship methodological approach aims to make the trainee acquaint with the world of work. The successful participation (attendance and filled in Internship Diary) is a prerequisite to participate in the final exam. Module content, Internship, Internship Diary and final exam are seen in a holistic manner, interconnected to each other. The final exam demands to incorporate a relevant piece from the internship's world of work into a demonstration lesson, thus, relating the lesson to the world of work by introducing a didactical relation for the competencies to be achieved by the trainees' students. The exam is held in front of an independent panel with an external verifier and evaluated by an exam matrix. Finally, the observations during the exam also allow the TTTI as an institution to spot areas of improvement for their in-service approach, contributing to evidence based quality improvement through a closed loop approach, as in (Anderson et. Al, 1994).

\subsection{Scaling up Phase}

Since the TTTI has in its profile to train a new generation of Master Trainers TTTI introduced to offer the most outstanding students, (who have finished their internship successfully, but still study), the opportunity, to serve as peer-mentors on various internship aspects in supporting their colleagues, such as finding the right company, or on aspects of the Internship Diary, or how to translate internship findings into a lesson. Through their support, the peer mentors themselves gain further access to companies in their field of teaching and become more acquaint with educational matters. (The peer approach is well accepted by TTTI trainees).

\subsection{Academic and closed loop phase}

In this phase the internship becomes an additional connotation and serves as an interface between trainee, TTTI institute and company. Feedback from trainees, or additional company contacts allow TTTI to establish a broader database for further research leading to a closed loop quality assurance approach, allowing for an evidence based further institutional development of the TTTI and the TVET in-service training and.

\section{Results And Discussion}

From the enrolled trainees at TTTI, a total of twenty seven participated in internships. The number of participants in internship has been constant over two (out of two) cohorts. All trainees who started their internship were able to finish.

Table 3

Assessment of the internship experience

\begin{tabular}{llll}
\hline Year of enrolment & $\begin{array}{l}\text { No. of trainees } \\
\text { participating in } \\
\text { internship }\end{array}$ & $\begin{array}{l}\text { No. of trainees who } \\
\text { found an internship in } \\
\text { a self-reliant manner }\end{array}$ & $\begin{array}{l}\text { No. of TTTI trainees } \\
\text { stating that their } \\
\text { internship has been a } \\
\text { worthwhile experience }\end{array}$ \\
\hline 2013 & 12 & 12 & $12 / 12$ \\
2014 & 15 & 15 & $14 / 15^{\star}$
\end{tabular}

${ }^{\star}$ The feedback section by one trainee was left empty

$100 \%$ of TTTI trainees were able to find their internship places in a self-reliant manner. $96 \%$ of the TTTI's trainees participating in an internship rated their participation a worthwhile experience. TTTI trainees undergoing the self-reliant approach have come to positive results, i.e. trainees were able in finding a place for their internship by themselves in the world of work. The TTTI's methodological approach has produced twice positive results, i.e. in enrolment 2013 and in enrolment 2014. TTTI trainees participating in internship 
have become acquaint with the world of work they are preparing their students for. Informal feedback given by companies is very favorable in establishing relationships with TTTI, e.g. through a Memorandum of Understanding (MoU). Through this methodological approach, the TTTI sees itself in line with its research to contributing to needed answers stemming from the interdependency of Afghan TVET policies, industrial and public sector skills demands and the students well being, such as identifying further needed TVET research or the development of a TVET teacher profile, as suggested in (Maclean et. al, 2011) (Rauner et. al, 2008).

\section{Conclusions}

In order to make the Afghan TVET teachers acquaint with the world of work, TTTI introduced for its trainees the participation in a self-reliant internship in the world of work. The TTTI's methodological approach has led to positive results also with regard to establishing an evidence based closed loop quality assurance approach for the institutional and academic capacity building. Finally, it can be concluded that the TTTI's methodological approach of introducing a self-reliant internship for TVET teacher has produced stable and positive results, even in Afghanistan's complex situation.

\section{Acknowledgments}

H.E. Deputy Minister Asif Nang, supporting the TTTI to implement self reliant internships in Afghanistan. Eng. Hag, Director Technical Teacher Training Directorate, Afghanistan to support the promotion of TTTI. ASDP-II Project Director Wahidulla Madani, for the management support and logistics. The World Bank's management team in Kabul and Dubai for supporting the Afghan systems delivery through in-service teacher training. Dr.Dr.Hans-Dieter Hoepfner for his academic advice and support to this publication.To all TTTI trainees for their support and vivid participation in their internship.

\section{References}

Anderson, J. C., Rungtusanatham, M. and Schroeder, R.G., (1994) A theory of quality management underlying the Deming management method, ACAD MANAGE REV, Vol. 19:3, (July), pp 472-509. doi:10.5465/AMR.1994.9412271808.

Maclean, R., (2011) 'Key Issues and Research Challenges for TVET: Bridging the gap between TVET research and the needs of policy makers', in NORRAG NEWS,Towards a New Global World of Skills Development? TVET's turn to Make its Mark, No.46, September 2011, pp. 125-127, available: http://www.norrag.org

Rauner, F., Mclean, R., (2008) Handbook of Technical and Vocational Education and Training Research, Springer Science and Business Media B.V. pp 14-18. doi 10.1007/978-1-40208347-1

USAID, (2012) TVET needs assessment for AWDP, Supply and demand in Afghanistan's six largest Cities http://www.crea-awdp.com/wp-content/uploads/2012/12/LM-and-TVET-needs-assesment-by-Startegic-

Social.pdf. Unpublished. p. 4-69. Last accessed 4 August 2014

World Bank, (2013), Emergency Project paper on a proposed grant in the amount of sdr 35.75 million (us $\$$ 55 million equivalent) to the Islamic Republic of Afghanistan for a second skills development project. No: 74711-AF (January). Unpublished. p 2-22, Last accessed 03 August 2014 http://moe.gov.af/Content/files/ASDP\%20Project\%20for\%202013-2018-eng.pdf. 